\begin{abstract}
The article interrelates topics related to hunger, poverty, human rights, nutrition and lack of empowerment of vulnerable citizens. These perspectives within the field of bioethics seek to provoke reflection on human frailty in the face of poverty and hunger. The text discusses the legacies of Josué de Castro, Paulo Freire, John Rawls and Amartya Sen, at a time when the right to food is being dicussed, in view of the ominous dimensions of world hunger. We reflect on the inequitable and unsatisfactory distribution of food, which is a source of life and survival. In defining empowerment as freedom and development of the individual, his collectivity and his relationships, the study indicates that hunger is suffering, and this calls for multidimensional reflection. The eradication of hunger is therefore a task required of all who seek the observance of full citizenship rigths. Keywords: Bioethics. Equity. Human rights. Hunger. Social justice. Poverty.
\end{abstract}

\title{
Resumo
}

\section{A fragilidade humana diante da pobreza e da fome}

O presente artigo busca realizar aproximação entre os temas que guardam relação com a fome, a pobreza, os direitos humanos, a alimentação e a falta de empoderamento dos cidadãos vulnerados. Essas perspectivas assumidas no campo da bioética tentam refletir sobre a fragilidade humana diante da pobreza e da fome. Aborda os legados de Josué de Castro, Paulo Freire, John Rawls e Amartya Sen ao momento em que se discute o direito a alimentação, tendo em vista as dimensões assustadoras da fome no mundo. Busca-se refletir sobre a iniquidade e a insatisfatória distribuição do alimento como fonte de vida e sobrevivência. Ao definir o empoderamento como liberdade e desenvolvimento do indivíduo, do seu coletivo e das suas relações, o estudo sinaliza que a fome é sofrimento que remete à reflexão multidimensional. A erradicação da fome é, portanto, tarefa que se impõe a todos os que buscam o pleno exercício da cidadania.

Palavras-chave: Bioética. Direitos humanos. Equidade. Fome. Justiça social. Pobreza.

\section{Resumen}

\section{La fragilidad humana frente a la pobreza y el hambre}

El presente artículo busca realizar una aproximación entre los temas del hambre, la pobreza, los derechos humanos, la alimentación y la falta de empoderamiento de los ciudadanos vulnerables. Estos enfoques adoptados en el ámbito de la bioética intentan reflexionar sobre la fragilidad humana frente a la pobreza y el hambre. Se analiza el legado de Josué de Castro, Paulo Freire, John Rawls y Amartya Sen justo en el momento en que debatimos sobre el derecho a la alimentación, teniendo en cuenta las alarmantes dimensions del hambre en el mundo. El artículo busca reflexionar sobre la iniquidad y la mala distribución equitativa de los alimentos como fuente de vida y supervivencia. Al asumir el empoderamiento como libertad y desarrollo de la persona, de su colectivo y de sus relaciones, el estudio indica que el hambre es un sufrimiento que remite a una reflexión multidimensional. La erradicación del hambre es una tarea que se impone a todos los que buscan el pleno ejercicio de la ciudadanía.

Palabras-clave: Bioética. Derechos humanos. Equidad. Hambre. Justicia social. Pobreza.

1. Doutora caroline.rosaneli@gmail.com 2. Especialista nutrianaribeiro@gmail.com 3. Especialista luanadeassis01@gmail.com 4. Especialista taniamasilva@ibest.com.br 5. Doutor eduardo.jose@pucpr.br - Pontifícia Universidade Católica do Paraná, Curitiba/PR, Brasil.

\section{Correspondência}

Caroline Filla Rosaneli - PUCPR, Escola de Saúde e Biociências, Programa de Mestrado em Bioética (PPGB). Rua Imaculada Conceição, 1.155, Prado Velho CEP 80215-901. Curitiba/PR, Brasil.

Declaram não haver conflito de interesse. 
Poverty is a complex multidimensional phenomenon that deprives a large portion of the world population of access to food, generating a huge human contingent fated to insufficient physical, psychological and social development. Inequality in opportunities concerning education, political participation and health care are the factors that keep these people subjected to these conditions of extreme poorness.

In Brazil, the eradication of extreme poverty has been more effective than the fight against hunger, as demonstrated by the reduction in the number of people below the line of poverty in relation to the reduction of malnutrition indices in the last thirty years in the country ${ }^{1}$. Malnutrition is a phenomenon resulting from the lack of social insertion and lack of access to adequate health care, housing and income which, in the words of Valente ${ }^{2}$, explains the maintenance of the state of social exclusion prevalent in our midst.

Likewise, the maintenance of the conditions of inequality leading to poverty and generating chronic hunger has serious consequences on the performance on the education of people living in Latin America. The low indices of access to regular education in ample strata of the population in the continent call attention to a perverse mechanism of transmission of poverty within generations ${ }^{3}$.

The eradication of extreme poverty was included as a priority goal in the agenda for the Objectives of the Millennium, intended to ban the most iniquitous of the problems of contemporary society. With the aim to reduce the number of people suffering from hunger, 186 nations subscribed the commitment to eradicate hunger in the world by 2015 . It should be noted that extreme poverty is still a reality in the everyday lives of 1 billion people in the world. However, it is estimated that at least 53 million will not be able to leave this situation of poverty in the time frame agreed by the nations ${ }^{1}$.

In Brazil, the contingent in the situation of extreme hunger totals 16.27 million people, representing $8.5 \%$ of the population of the country. The largest number of these (59.1\%) are in the Northeast region, totaling 9.61 million people. Of the 8.67 million extremely poor people living in urban areas, a little over half live in the Northeast (52.6\%) and about one in four live in the Southeast region $(24.7 \%)^{4}$.

In the analysis made by Narayan ${ }^{5}$, the poor crave to reach the condition of agents of their own destinies. Research with people affected by poverty in several countries shows evidence of how discour- aging and unreachable the possibilities to fulfill this desideratum are. It seems obvious that the lack of empowerment of this socially excluded contingent represents the fundamental obstacle to the full exercise of their citizenship, thus depriving them of the status of autonomous persons and holders of their own rights. The impossibility to access healthy eating, associated with absolute poverty, is what keeps them in the condition of social exclusion and which demeans them in their dignity ${ }^{6}$.

The reflections in this article seek a rapprochement between hunger, poverty, human rights, power and the lack of empowerment of citizens made vulnerable ${ }^{7}$. It also seeks to stimulate the reader's insights on the theme that is so difficult to resolve in a society who witnesses, without reaction, a predatory capitalism at the same time as it allows for the increasing accumulation of the world's wealth in the hands of just a few and sentences millions of people around the globe to social death.

The objective of this paper is to propose a reflection on human frailty in the face of poverty and hunger. Likewise, it seeks to identify, through literature, alternatives that could pave the way to the so desired level of personal empowerment, the essential condition for authentic expression of active citizenship.

\section{The dimensions of human poverty}

It is not an easy task to understand all the inhuman dimensions of extreme poverty, as there are so many variables comprising this ailment. However, for those experimenting this reality, everything can be summed up to the single condition of having three meals a day to rid them of "the pain of hunger" 5,8 . Crespo and Gurovitz ${ }^{9}$, analyzing the different components of the concept of poverty formulated in the $X^{\text {th }}$ century, identified the following dimensions, considered essential: physical survival, basic needs of access to food, health, housing, and basic sanitation.

Salama and Destremau ${ }^{10}$ state that poverty has many faces and dimensions and may be perceived and experienced in different ways by different groups. Such subjectivity, linked to the feeling of deprivation, opens new possibilities of analysis for these dimensions. The criteria that deal with social inequities, linked to factors of income inequality and to the causes of poverty, bring to the surface the theme of relative poverty, in opposition to absolute poverty, which would deprive the person of access to the most elementary needs of physical survival ${ }^{11}$. 
According to Amartya Sen ${ }^{12}$, reducing the concept of poverty to the mere condition of not having enough personal income would consist in unacceptable reductionism. Poverty must be understood as a much broader condition of deprivation, concerning human existence and personal dignity, as it cannot be regarded and an end in itself and never as a means, according to the Kantian imperative. The possibility of freely manifesting one's full personal potentials must be assured to every individual and, as a consequence, the development of the ability to autonomously insert oneself into the job market should allow every person to have a personal income that is sufficient to provide the condition of a citizen with rights.

Starting from a purely biological assumption, it would be possible to define hunger and absolute poverty as the condition of non fulfillment the minimal nutritional requirements of a conventional diet that allows the individual to perform physical, intellectual and labor activities characteristic of a regular human being ${ }^{9}$. It is important, however, to keep in mind that limiting the concept of poverty solely to nutritional needs would be a serious mistake, as underestimating other variables, such as family life, harmonic social acceptance and the sense of belonging would be equivalent to reducing the person to an animal, not human, state ${ }^{13}$.

It seems obvious, thus, that depriving the common citizen of enough personal income to provide proper food for the family is the same as sentencing the citizen and everyone who depends on him/her to food insecurity and its undesirable adverse consequences ${ }^{6}$. Among the several definitions formulated in the 1980s, it seems reasonable to accept the one which considers poverty as the relative deprivation of proper food, physical comfort and social inclusion ${ }^{9}$.

Sen ${ }^{12}$ considers that the concept of relative deprivation must be broadened to include other types of needs. Thus, the author went on to define it as deprivation of basic human capabilities, disregarding everything that intends to reduce it merely to the lack of personal or family income. However, there is nos doubt that human life becomes extremely vulnerable when facing the situation of lack of family income, i.e. the lack of minimum income inevitably leads people to hunger, social helplessness and low self-esteem. This course of events will only be changed, according to Antunes ${ }^{14}$, when the vulnerable acquire effective power do make autonomous decisions about their own lives, which has been termed empowerment, in English (empoderamento, in Portuguese) which we think would be better understood (in Portuguese) if translated to "emancipação" (emancipation) or "libertação" (liberation), as proposed by Paulo Freire. As Narayan ${ }^{5}$ put it, empowerment would express the condition in which the poor become agents of their own destiny and, therefore, citizens of rights.

\section{Justice as equity}

According to Rawls ${ }^{15}$, justice is the first virtue of social institutions, as truth is of systems of thought. This author developed a theory of justice from the assumption of social equity; it is argued that the social contract will only be fair if all members of a community are considered as citizens apt to participate in the decision making processes, with equal rights, provided they are protected by a "veil of ignorance".

Rawls believes that people two principles of justice from this assumption: the first would offer the same basic liberties to all citizens, such as expression and religion, and the second principle would lead to the sens of social and economic equity, granting benefits to the least favored members of the society ${ }^{16}$.

Justice as equity would thus establish the original accord through the principles of justice that determine the basic structure for the society ${ }^{17}$. Rawls's proposition regards a society as a broad cooperation system that would seek the mutual benefit through the good will of everyone. This way, it would be necessary that the terms of the cooperation were fair and that the principles of justice as equity could determine the rules in which this were achieved ${ }^{18}$. In this line of reasoning, the primordial objective of justice would be to build a truly equanimous society, which would allow for the fair outline of the way in which different social institutions would recognize rights and perform the equitable distribution of advantages coming from mutual cooperation.

Considering healthy eating a fundamental right, The Universal Declaration of Human Rights establishes, in its article 25 item (1), that Everyone has the right to a standard of living adequate for the health and well-being of himself and of his family, including food, clothing, housing and medical care and necessary social services, and the right to security in the event of unemployment, sickness, disability, widowhood, old age or other lack of livelihood in circumstances beyond his control ${ }^{19}$. In agreement with the theory of Rawls and The Universal Declaration of Human Rights, article 10 of the Universal Decla- 
ration on Bioethics and Human Rights, by Unesco, establishes that The fundamental equality of all human beings in dignity and rights is to be respected so that they are treated justly and equitably ${ }^{20}$.

When analyzing the data that scale the lack of access to safe and proper food, one can see the injustice in the attainment of that fundamental right and the immoral persistence of hunger in times of agricultural production that is sufficient to bring food to the table of all Brazilians. Despite being a great world producer of food, Brazil has not, to date, been able to establish public policies to fully attain this right.

Another problem, that goes beyond the scope of this essay and which should receive the attention of our public authorities, is the waste of food. According to data from the World Bank ${ }^{21}$, between one third and one fourth of the food produced for human consumption worldwide yearly goes to waste. This is equivalent to saying that, every year, around 1.3 billion tons of food are disposed of, including $30 \%$ of grains, $40 \%$ to $50 \%$ of roots, fruits, vegetables and oilseeds, $20 \%$ of meat and dairy products and $35 \%$ of fish.

Besides its huge impact on food safety, the loss of food compromises the performance of the global economy, considering the waste of human labor and natural resources involved in its production - circumstances that contribute to the maintenance of absolute poverty. According to The Food and Agriculture Organization of the United Nations (FAO) ${ }^{22}$, these losses take place along the whole production chain, being that $28 \%$ of them occur due to waste of the consumers themselves; another $28 \%$, occur in the production system; $17 \%$, in trading and distribution; $22 \%$, during handling and storage; and $5 \%$ are due to inadequate processing of food.

It must also be considered that food products considered inadequate for commercialization contain significant nutritional values and may be used for human consumption. On the other hand, Rawls's theory poses an uncomfortable reflection as it questions the extent to which one should blame only the government for the bad management of the public wealth, and what the realm magnitude is of the lack of effort of the regular citizen in contributing to solve problems that affect the whole community which one is a part, as is the case of food deprivation to a large contingent of people living around those who discard food as garbage. So, what is the share of responsibility of each of us for the maintenance of this shameful reality of living with people who suffer of chronic hunger, people we insist in sot seeing although they're around us on the streets of our neighborhoods?

\section{The pain of hunger}

There is no doubt that the right to food is, among all the rights listed in the United Nations' International Covenant on Economic, Social and Cultural Rights (ICESCR) ${ }^{23}$, the most unattended in the world. The FAO estimates that, of the 6.7 billion people on the planet, Almost 1 billion suffer with chronic hunger ${ }^{24}$. The damage caused by hunger is not only physical, but may also result in irreversible neurological damage along with cognitive and emotional damages. Debilitated physically and mentally, the underfed human being becomes vulnerable and shows organic functions and the ability to perform regular work ${ }^{24}$. In this functional and physiological complexity, one can think that the "pain of hunger" is impossible to understand for those who do not suffer from it, being witnessed but not felt.

According to Valente, to see one's children starve is [equally] to starve. To eat garbage is to starve. To eat leftovers from the plates of others is starving. To eat [only] once a day is to starve. Having to go through humiliation to get a basket of food is to starve. To exchange one's dignity for food is to starve. To be afraid of starvation is to be a prisoner of hunger ${ }^{25}$. The respected Brazilian researcher Eliane Azevêdo ${ }^{26}$ has shown that hunger associated to extreme poverty, when present since the first days of life of a child, practically sentences this human being to being chronically undernourished, physically and mentally handicapped, definitely deprived of the future exercise of citizenship.

Data presented by Azevêdo ${ }^{26}$ are in agreement with other publications that show that undernourishment in the first five years of life is responsible for irreversible damage to the development of the central nervous system ${ }^{24}$. Even more serious, however, is the fact that many of these children suffer the consequences of this calamity before birth, in the womb of theirs mothers which are themselves victims of chronic undernourishment.

In order to better understand the damages resulting from the bad distribution of food in the world, it is necessary to distinguish structural hunger from conjunctural hunger. The former is permanent, the one that destroys the person's body, mind, and dignity, the main responsible for imposing a state of suffering that will only be extinct with the death of that human being. The latter happens episodically, depending on consequences of natural catastrophes such as earthquakes and floods, or in wars that affect the economic development of the countries involved ${ }^{24}$. 
Ziegler ${ }^{24}$ considers that there are three population groups which are more vulnerable to conjunctural hunger: the poor in rural areas, the urban poor and the poor which are victims of environmental catastrophes such as the earthquake that hit Haiti in 2010. Circa 900 million people who live in rural areas are in absolute poverty, and the urban poor reach the figure of $\mathbf{3 0 0}$ million. Poor populations in urban areas - who live on insufficient family income, generally live in the outskirts of large cities, clustered in huge slums ("favelas") and deprived of the most elementary services of urban sanitation constitute, in their majority, the socially excluded, those without the minimal conditions that would allow them to enjoy human life with dignity.

Data from the Pan American Health Organization ${ }^{27}$, for Latin America and the Caribbean show a huge contingent of 47 million undernourished people, of which 7.1 million are children below the age of 5 who suffer from chronic malnutrition. According to data form the United Nations Children's Fund (Unicef) ${ }^{28}$, one third of the population of the world is incapable to develop its physical and intellectual potential due to food shortage, potential victims of the numerous diseases related to low immunity. Human beings that do not have enough food to fulfill their basic organic needs invariably feel they are losing their personal dignity and show low self-esteem. This way, absolute poverty affects the individual, the family and the whole community, considering its potential to produce harmful effects on different dimensions of human life. Buss ${ }^{29}$ considers that [the ones who] have the worst [levels of] income are exactly those who, besides being in the most need, also have the worst access to public policies for housing, drinking water, sanitation, food, education, transport, leisure, steady jobs and health services, which [characterizes] the so-called social and health inequities ${ }^{30}$. The suffering and the incapabilities generated by chronic hunger turn life into a martyrdom, conditions that affront the most elementary principles of human dignity.

\section{The legacy of Josué de Castro}

In 1935, Josué de Castro already showed concerns with the combination of human dignity and access to food, as he acknowledged that the disease affecting the patients that worked was a result of hunger associated to poverty. As he performed the first food research in Brazil, he made essential contributions to the promotion of public policies to ensure a proper minimum wage and to allow the access of workers to healthy food, which would spare them the suffering posed by food insecurity. At the time, he proposed a basic food basket which, although compromised half of the wage of regular workers, would be enough to fulfill $100 \%$ of the nutritional requirements of calories, proteins, minerals and essential vitamins ${ }^{31}$.

Castro, one of the most acclaimed researchers on the issue of hunger, an intellectual gifted with prophetical vision and active militant for human rights, left us a great legacy on the matter as he demonstrated that hunger caused by the adoption of wrong public policies may be overcome through the promotion of feasible social projects aiming at the people who needed them most. In a peculiar personal assessment, he inferred that this could explain the large progenies of extremely poor people, as the unfounded hope they kept that the large number of children would ensure safety and protection in their old age.

From the concept of food insecurity he formulated the metaphor in which we all live in a society of sleepless people: those who would not sleep for suffering from the pains resulting from chronic hunger and, on the other side, those who would suffer from insomnia for being dominated by the constant fear of being victims of the aggression promoted by the chronically hungry. It is obvious that building a harmonic and pacific society in these circumstances becomes an impossible task, especially if we consider the mistaken repressive attitudes adopted by several public authorities to keep the poor who suffer from the "pain of hunger" from publicly expressing their justified anguish ${ }^{24}$.

In the understanding of Castro ${ }^{6}$, the solution to the problem of hunger and absolute poverty would only be reached by means of public policies for the social inclusion and access to food safety to all inhabitants of the modern polis, which would require the completion of a land reform and the promotion of fair income distribution ${ }^{32}$. It is important to highlight that food insecurity and chronic hunger deriving from it generate a vicious circle that can only be interrupted if the offer of food for consumption is sufficient and accessible to all workers and their dependents.

\section{The human right to adequate food}

Human rights were established in international statements and treaties with the participation of representatives of all nations in the world, who 
subscribed them in the name of all mankind. These treaties define, among other duties, the obligation of National States to respect, protect, promote and provide human rights to all. Food safety is among those rights as a vital need for all citizens. The Human Right to Adequate Food (HRtAF) will only be a reality when all the people, regardless of social class, nationality or ethnic group, have permanent access to healthy food and to proper means for its acquisition. According to the annual report of the Commission for Monitoring the $\mathrm{HRtAF}^{33}$, the term adequate food, besides the specification of the list of indispensable items to consider the food to be healthy, also identifies the cultural elements peculiar to each human community, such as physical and financial accessibility, nutritional value of food items, variety of available products, social and environmental sustainability and respect to religious and ethnic issues.

Despite all effort the countries dedicate to seek solutions to make food safety available for all, according to the UN report ${ }^{22}$, hunger still affects approximately 842 million people worldwide. In this context, the permanence of hunger and absolute poverty does not secure the HRtAF, generating inequity, inequality and compromising social peace. Considering this, it is clear that, for the complete fulfillment of the HRtAF, it is necessary that national States invest more in public policies for social inclusion to combat the problem of hunger. The effective satisfaction of the HRtAF also requires incentives for family farming, the adoption of policies of basic sanitation, school meals, prenatal care, breastfeeding programs and the promotion of legal measures to avoid any type of social discrimination ${ }^{34}$.

There is consensus that the development of civilization and the evolution of our species only became possible with the certainty of food safety for most people ${ }^{35}$, so that any goal below $100 \%$ of food safety is simply unacceptable ${ }^{36}$. According to Batista ${ }^{31}$, there is the need for a model of economic, social, political and cultural development to allow Brazil to continuously offer its population food and nutritional safety, a necessary goal to make possible the reduction of the huge social exclusion prevalent in country.

In the analysis by Sen ${ }^{37}$, food safety and the promotion of personal liberty constitute essential conditions to ensure that any human community take the true status of a democratic State under the law. The sovereignty of a country in food production is not, in itself, sufficient to prevent its population suffering from hunger or to ensure the fulfillment of the HRtAF. Taking Brazil as an example, serious irregularities can be observed in the chain of food production, from storage to commercialization and consumption, factors that, unattended, compromise the realization of the HRtAF ${ }^{31}$.

\section{Empowerment as an element of combat against poverty}

According to Gohn ${ }^{38}$, the empowerment of the people certainly has a positive impact on the expression of citizenship as well as on the self-esteem of the population. This author shows that the pedagogical model proposed by Paulo Freire, as it privileges the intrinsic potentials of each person, constitutes the essential incentive to improve their conditions of life. The educator from Pernambuco preferred the word emancipation instead of empowerment to express the active process of social inclusion of people affected by hunger and extreme poverty ${ }^{39}$.

It is important to take into account that no government or external social agent will promote the empowerment of people but themselves in the continuous search to impose themselves as citizens with rights ${ }^{12}$. In the combat against poverty, to empower the socially excluded implies permission for their personal abilities to surface, as well as their community organizations, in order to allow them to achieve the status of legitimate interlocutors, capable of taking part in real community communication. Thus, empowerment or emancipation means the creation of conditions to overcome the obstacles that limit the free expression of people in the search to fulfill their own choices; or, better, it would be the means to erect new standards in the balance or power among the members of a democratic society.

According to Romano ${ }^{39}$, empowerment is a means to construct a possible future, tangible, with the capability to recover the hopes of the population and to mobilize their energies for the struggle for rights in the local, national and international scales. But empowerment is also an end, because the power is in the essence of the definition and overcoming of poverty. Empowerment needs to be constantly renewed to assure that the correlation of forces does not return to producing the relationships of domination that characterize poverty ${ }^{40}$.

Freire and Shor ${ }^{41}$ state that emancipation must not be considered as individual expression or that of small communities, but an achievement for active citizenship of the society as a whole. This level of citizenship can only thrive in an environment that cultivates participatory democracy and the respect for human rights, in which all individuals may 
express themselves as emancipated people in their everyday actions - be them economic, political or cultural - according to their own argumentative resources and as subjects of rights that interact in a real communication community ${ }^{42}$ : empowerment as process and result may be conceived as emerging from a process of social action in which individuals take possession of their own lives through interaction with other individuals, generating critical thought in relation to reality, favoring the construction of personal and social capabilities and making possible the transformation of the social relations of power ${ }^{43}$. In this sense, an instrument that proved effective to promote emancipation is the one supplied by liberating education, the pedagogical model proposed by Paulo Freire ${ }^{44}$.

In sum. The fundamental element in the fight against absolute poverty will be the investment in active learning methodologies allied to participatory education which can give individuals the ability to free themselves form the ties of external dependencies, becoming autonomous people, apt to take part as moral subjects with rights in their original communities ${ }^{45}$.

\section{Final considerations}

In defending the empowerment as an essential element for the promotion of liberty and the development of citizenship, we recognize that the present paper presents only a modest reflection on the theme of such social relevance and which must deserve the attention of other researchers in the sense of promoting new inputs in order to improve the knowledge on hunger, absolute poverty, food insecurity as well their serious repercussions on the quality of life of human beings.

We know that the present food production in the world is sufficient to provide for the needs of all inhabitants of the planet; therefore, the eradication of hunger is not only possible but must also be taken as an inescapable commitment of all national governments.

Mankind claims for Paulo Freire's liberating education and to overcome persisting social inequities ${ }^{46}$. Amartya Sen, in his work "The idea of justice", dedicated to John Rawls, presents, in the preface, a reflection that is worth highlighting: What moves us, reasonably enough, is not the realization that the world falls short of being completely just - which few of us expect - but that there are clearly remediable injustices around us which we want to eliminate ${ }^{47}$. The last question we consider necessary to aggregate to Sen's lucid thought refers to the behavior of all as persons responsible for social peace and participants of a society that pursues the ideal of human solidarity: Are we really making an effort to eliminate form our surroundings the serious social injustices that affect almost 17 million Brazilians in absolute poverty who suffer food insecurity every day?

\section{Referências}

1. Programa das Nações Unidas para o Desenvolvimento. Erradicar a pobreza e a fome. Objetivos do Milênio. [Internet]. 2000 [acesso 15 ago 2014]. Disponível: http://www.pnud.org.br/ODM1.aspx

2. Valente FLS. Fome, desnutrição e cidadania: inclusão social e direitos humanos. Saúde e Sociedade. 2003;12(1):51-60.

3. Naciones Unidas. Objetivos de desarrollo del milenio: una mirada desde América Latina y el Caribe. Santiago de Chile: Naciones Unidas; 2005.

4. Ministério do Desenvolvimento Social e Combate à Fome (Brasil). O perfil da extrema pobreza no Brasil com base nos dados preliminares do universo do Censo 2010. Brasília; 2 maio 2011. (Nota).

5. Narayan D, Chambers R, Shan MK, Petesch P (World Bank). Voices of the poor: Crying out for change. Nova York: Oxford University Press; 2000.

6. Food and Agriculture Organization of the United Nations. The state of food and agriculture 2006. Food aid for food security? Roma: FAO; 2006.

7. Schramm FR. Bioética da proteção: ferramenta válida para enfrentar problemas morais na era da globalização. Rev. bioét. (Impr.). 2008;16(1):17.

8. Sen A. Desenvolvimento como liberdade. São Paulo: Companhia das Letras; 2000.

9. Crespo APA, Gurovitz E. A pobreza como um fenômeno multidimensional. ERA-eletrônica. 2002;1(2):1-12.

10. Salama P, Destremau B. O tamanho da pobreza: economia política e distribuição da renda. Rio de Janeiro: Garamond; 1999.

11. Garcia AV. A pobreza humana: concepções, causas e soluções. Florianópolis: Editoria em Debate; 2012.

12. Sen A. Pobreza e fomes: um ensaio sobre direitos e privações. Lisboa: Terramar; 1999. 
13. Santos GC, Arcoverde ACB. Pobreza: conceitos, mensuração e enfrentamento no Brasil. Anais da 5a Jornada Internacional de Políticas Públicas: 2011 ago 23-26; São Luís do Maranhão, Brasil. [Internet]. São Luís: UFMA; 2011 [acesso 6 jul 2014]. Disponível: http://www.joinpp.ufma. br/jornadas/joinpp2011/CdVjornada/JORNADA_EIXO_2011/DESIGUALDADES_SOCIAIS_E_ POBREZA/POBREZA_CONCEITOS_MENSURACAO_E_ENFRENTAMENTO_NO_BRASIL.pdf

14. Antunes M. O caminho do empoderamento: articulando as noções de desenvolvimento, pobreza e empoderamento. In: Romano JO, Antunes M, organizadores. Empoderamento e direitos no combate à pobreza. Rio de Janeiro: ActionAid Brasil; 2002.

15. Rawls J. Uma teoria da justiça. São Paulo: Martins Fontes; 1997. p. 3.

16. Rawls J. Op. cit. p. 16.

17. Rawls J. Op. cit. p. 160.

18. Rawls J. Justiça como equidade. São Paulo: Martins Fontes; 2003.

19. Organização das Nações Unidas. Declaração universal dos direitos humanos. ONU; 1948. Disponível: http://www.dhnet.org.br/direitos/deconu/textos/integra.htm [acesso 2 dez 2014].

20. Organização das Nações Unidas para a Educação, a Ciência e a Cultura. Declaração Universal sobre Bioética e Direitos Humanos. Comissão Nacional da Unesco-Portugal, tradutor. [Internet]. Paris: Unesco; 2005 [acesso 2 dez 2014]. Disponível: http://unesdoc.unesco.org/ images/0014/001461/146180por.pdf

21. World Bank. Food Price Watch, february 2014: Prices decline at a slower pace; focus on food loss and waste. [Internet]. fev 2014 [acesso 20 jul 2014]. Disponível: http://www.worldbank.org/en/ topic/poverty/publication/food-price-watch-february-2014

22. Organización de las Naciones Unidas para la Alimentación y la Agricultura. Pérdidas y desperdicios de alimentos en América Latina y el Caribe. [Internet]. 2014 [acesso 5 jul 2014]. Disponível: http://www.fao.org/3/a-i3942s.pdf

23. Organização das Nações Unidas. Pacto Internacional sobre Direitos Econômicos, Sociais e Culturais. [Internet]. 1966 [acesso 2 dez 2014]. Disponível: http://www.unfpa.org.br/Arquivos/ pacto_internacional.pdf

24. Ziegler J. Destruição em massa: geopolítica da fome. São Paulo: Cortez; 2013.

25. Valente FLS. Op. cit. p. 57.

26. Azêvedo EES. O direito de vir a ser após o nascimento. Porto Alegre: EdiPUCRS; 2002.

27. Organización Panamericana de la Salud. Una mirada integral a las políticas públicas de agricultura familiar, seguridad alimentaria, nutrición y salud pública en las Américas: acercando agendas de trabajo en las Naciones Unidas. [Internet]. 2014 maio [acesso 6 jul 2014]. Disponível: http://www. fao.org/fileadmin/user_upload/rlc/eventos/231982/doc_20140509_es.pdf

28. Fundo das Nações Unidas para a Infância. Situação mundial da infância 2006: excluídas e invisíveis. Nova York: Unicef; 2006 [acesso 14 ago 2014]. Disponível: https://www.unicef.pt/18/ relatorio_sowc06.pdf

29. Buss PM. Globalização, pobreza e saúde. Cienc Saúde Coletiva. 2007;12(6):1.575-89.

30. Buss PM. Op. cit. p. 1.578.

31. Batista Filho M. Da fome à segurança alimentar: retrospecto e visão prospectiva. Cad Saúde Pública. [Internet]. 2003;19(4):872-3. [acesso 1 mar 2015]. Disponível: http://www.scielo.br/ scielo.php?script=sci_arttext\&pid=S0102-311X2003000400001\&lng=pt

32. Santos KH. Josué de Castro: fome e repercussões sociais. Serviço Social \& Saúde. 2011;10(11):5989.

33. Comissão Especial de Monitoramento de Violação do Direito Humano à Alimentação Adequada (Secretaria dos Direitos Humanos). Relatório anual. [Internet]. Brasília; nov 2011 [acesso 15 jul 2014]. Disponível: http://www.sdh.gov.br/sobre/participacao-social/cddph/relatorios/relatorioc.e-alimentacao-adequada

34. Ação Brasileira pela Nutrição e Direitos Humanos. O direito humano à alimentação adequada e o Sistema Nacional de Segurança Alimentar e Nutricional. [Internet]. Brasília: MDS; 2013 [acesso 18 jul 2014]. Disponível: http://www.mds.gov.br/segurancaalimentar/publicacoes\%20 sisan/o-direito-humano-a-alimentacao-adequada-e-o-sistema-nacional-de-seguranca-alimentare-nutricional

35. Panigassi G, Segall-Corrêa AM, Marin-León L, Pérez-Escamilla R, Sampaio MFA, Maranha LK. Insegurança alimentar como indicador de iniquidade: análise de inquérito populacional. Cad Saúde Pública. [Internet]. 2008;24:(10):2.376-84. [acesso 10 mar 2015]. Disponível: http://www. scielo.br/scielo.php?script=sci_arttext\&pid=S0102-311X2008001000018

36. Alencar AG. Do conceito estratégico de segurança alimentar ao plano de ação da FAO para combater a fome. Rev Bras Polít Int. [Internet]. 2001;44(1):137-44. [acesso 1o mar 2015]. Disponível: http://dx.doi.org/10.1590/S0034-73292001000100009

37. Sen A. Food and freedom. World Dev. 1989;17(6):769-81.

38. Gohn MG. Empoderamento e participação da comunidade em políticas sociais. Saúde Soc. [Internet]. 2004;13(2):20-31. [acesso 10 mar 2015]. Disponível: http://www.scielo.br/scielo. php?pid=S0104-12902004000200003\&script=sci_arttext

39. Romano JO. Empoderamento: recuperando a questão do poder no combate à pobreza. In: Romano JO, Antunes $\mathrm{M}$, organizadores. Empoderamento e direitos no combate à pobreza. Rio de Janeiro: ActionAid Brasil; 2002. 
40. Romano JO. Op. cit. p. 19.

41. Freire P, Shor I. Medo e ousadia. O cotidiano do professor. Rio de Janeiro: Paz e Terra; 1986.

42. Baquero RVA. Empoderamento: instrumento de emancipação social? Uma discussão conceitual. Revista Debates. 2012;6(1):173-87.

43. Baquero RVA. Op. cit. p. 181

44. Freire P. Educação e mudança. São Paulo: Paz e Terra; 1979.

45. Freire P. Pedagogia da autonomia: saberes necessários à prática educativa. São Paulo: Paz e Terra; 1996. (Coleção Leitura).

46. Freire P. Pedagogia do oprimido. Rio de Janeiro: Paz e Terra; 2005.

47. Sen A. A ideia de justiça. São Paulo: Companhia das Letras; 2011. p. 9.

\section{Participation of the authors}

Caroline Filla Rosaneli and José Eduardo de Siqueira were responsible for the general conception of the article and for guiding the bibliographic research performed by Ana Lúcia Cardoso Ribeiro, Luana de Assis and Tânia Mara da Silva.

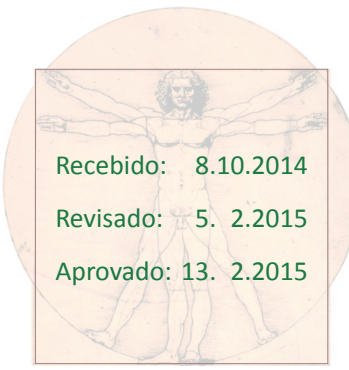

